\title{
Evaluation of Coconut Based Anacardium occidentale Agroforestry System to Improve the Soil Properties of Coconut Growing Lands in Wet, Intermediate and Dry Zone of Sri Lanka
}

\author{
S. H. S. Senarathne and S. S. Udumann
}

\begin{abstract}
This study was intended to assess the impact of coconut based Anacardium occidentale (Cashew) agroforestry systems on soil fertility of degraded coconut lands in wet, intermediate and dry zones of Sri Lanka. Two treatments were evaluated according to randomized complete block design with three replicates. Coconut based agroforestry systems intercropped with A. occidentale and sole coconut were evaluated as two treatments. Soils from three depths were analyzed for its' chemical, physical and biological properties.

According to the esults, higher total $\mathrm{N}$, available $\mathrm{P}$ and exchangeable $\mathrm{K}$ levels were shown in sole coconut systems than $A$. occidentale intercropped system while the higher total $\mathrm{N}$ levels $(2 \%$ higher than top soil and $27 \%$ higher than deepr soil) were observed in sub soils compared top and deep soils. Higher P content was observed in top soils than in deeper soils. The exchangeable $\mathrm{K}$ was observed in higher quantities in sub soil than in deeper soils and was varied with locations. Organic matter content in intercropping of $A$. occidentale has been increased by $37 \%$ and the highest was observed in top soils. Soil bulk density has been reduced by $9 \%$ in $A$. occidentale intercropped system enhancing the root growth. Bulk density has been increased with the depth of the soil. Higher soil microbial activity was observed in $A$. occidentale intercropped system and it was $22 \%$ higher than sole coconut system. Sole coconut system has $50 \%$ higher soil moisture percentage and the highest was recorded in sub soils. This study confirms that intercropping of $A$. occidentale has a positive effect on improving soil fertility of degraded coconut growing soils in wet, intermediate and dry zones of Sri Lanka.
\end{abstract}

Key words: Agroforestry, Coconut, $A$. occidentale, Dry zone, Intermediate zone

\section{Introduction}

Agroforestry is a form of land use that has long beenpracticed in many parts of the world (Regmi and Garforth, 2010) with the type and composition of tree species and their distribution and extent varying according to topography, biophysical attributes andthe socio-economic conditions of the resource managers. Agroforestry is commonly understood as the integration of trees or deliberate retention of trees on agricultural land (Nair 1985) where the primary objectives are to produce food, fodder, fuel-wood and/or timber. There can also be co-benefits such ascarbon sequestration, enhancing water quality, protecting soil and conserving biodiversity (Tamale et al., 1995; Arnold 1997; Long and

Agronomy Division, Coconut Research Institute, Lunuwila, Sri Lanka.

Email: shsumith71@yahoo.com 
Nair, 1999; Jose 2009; Alavalapati et al., 2004). Sustainability of this farming system is reflected by its appropriateness in the given economic and environmental circumstances. Coconut is one of the most widely grown tree crops in the tropics, occupying in some regions up to $20-30 \%$ of the total cultivated area. With its economic life span of 60 years or more, it occupies the land for a long time. As a monocrop, its economic life in some places averages only about 40 years, depending on growing conditions (Burgess, 1981 and Opio, 1990). Beyond this period, the productivity of the land under coconut diminishes, and thrfore, it is necessary to diversify the land use or to replant coconut.

The morphological characteristics of the coconut palm and the conventionally adopted spacing (ranging from $8 \times 8$ to $8.6 \times 8.6 \mathrm{~m}$ ) associated with the coconut root system which normally clusters within $2 \mathrm{~m}$ of the stem allow open spaces for further cultivation and/or grazing. At the much used spacing of $8 \times 8 \mathrm{~m}$, at least $64 \mathrm{~m}^{2}$ is actually allocated to each palm and yet the effective root area per palm is only $12.5 \mathrm{~m}^{2}$ or $15.4 \%$ of the available space leaving $68.5 \mathrm{~m}^{2}(84.6 \%)$ of spacing underutilized. Furthermore, as established by Nelliat et al., 1974 , the top $30 \mathrm{~cm}$ of soil is generally devoid of functional roots and $86 \%$ of the coconut roots are found between $30-130 \mathrm{~cm}$ depth. This suggests that coconut is by nature suited to intercropping. The unique leaf canopy permits a large part of the solar energy to be transmitted through it. The percentage of light transmitted depends on the age of the palms, ranging from $20 \%$ under $10-20$-year-old palms, to $50 \%$ in plantations of 40 years and over. In older plantations light transmission increases substantially, providing ideal conditions for coconut base farming systems (CBFS). To this extent, over $60 \%$ of smallholders practice CBFS. Intercropping is a major cropping system for coconut cultivation worldwide (Liyanage et al., 1985; Magat, 2004; Ohler, 2007). Intercropping represents a more efficient use of natural resourcesand labour (Fordham, 1983); broadensfarmer's income/ food security base and helpsin weed control (Bonneau and Sugarianto, 1999). There are many common annuals and perennials recommended for CBFS. Using productivity as a land value measure suggests that coconut land generates a very low return per unit area compared to other crop land. But in the plantation sector, where long-term crops such as bananas, coffee, cocoa, pineapple, cashew, mango, etc. are involved, continuous cropping is commonly practiced (Fernando et al., 1984).

Low land productivity in coconut plantations is highly associate with loss of fertile topsoil through accelerated erosion due to poor land management. Numerous studies have been undertaken to achieve this task through several agronomic practices, especially by improving fertility status of soil (Liyanage and Dasanayake, 1993). Incorporation of tree species producing substantial amounts of biomass is recognized as a solution for enhancing soil organic matter in cost effective way and with alternative uses (Costa and Sangakkara, 2006).

However, for coconut, inclusion of a Cashew (Anacardium occidentale L) based agroforestry system is possible using available spacing efficiently. In addition to the more organic matter incorporation and mining nutrients from subsoil with its deep root system. Systematic incorporation of Cashew is an effective barrier for reducing the momentum of raindrops and overland flow but diminishing the risk of erosion. Cashew being a hardy crop can thrive well in variety of soils and is usually grown in poor soils where no other horticultural crop can be grown successfully. The major area under cashew cultivation is located in marginal waste lands, coastal laterite and sandy soils and as an intercrop with mature coconut plantations of Sri Lanka.

Cashew (Anacardium occidentale L), is one of the cashcrops which is grown with coconut in selected areas in Sri Lanka. Cashew is becoming an important cash crop for farmers in Sri Lanka where there is greater potential for increased production for the local market and export market. Presently, approximately 42,000 ha are under cashew plantations and around $10,000 \mathrm{MT}$ of rawnuts are being produced which is only about $50 \%$ of the local demand (Weerakoon, 2011). Amongst the main areas of 
cashew cultivation namely Puttalam, Kurunegala, Batticaloa, Anuradhapura, Mannar and Hambanthota, coconut cashew intercropping systems can be mainly identified in Puttalam district in commercial scale. Therefore, this study was design to assess the potential of using coconut based $A$. occidentale agroforestry systems to improve soil fertility of degraded coconut lands in wet zone, intermediate zone and dry zone of Sri Lanka.

\section{Materials and Methods}

The study was conducted at Agronomy Division of Coconut Research Institute (CRI), Lunuwila, Sri Lanka, situated in North Western Province of Sri Lanka, ( $7^{\circ} 20^{\prime} 37^{\prime \prime}$ N, 79 $51^{\circ} 42^{\prime \prime}$ E). Study was carried out in established experiment fields for intercropped coconut. The first field experiment was established at Rathmalagara Estate, Madampe in the low country intermediate zone $\left(08^{0} 02^{\prime} \mathrm{N}, 79^{0} \mathrm{E} ; 35\right.$ $\mathrm{m}$ from mean sea level). Agro ecological zone of this area is $\mathrm{IL}_{1}$ (Punyawardena et al., 2003). Soils of this area belong to the Andigama series which categorized into great soil group of Red Yellow Podzolic (Mapa et al., 2005) (Ferric Acrisols; FAO/ UNESCO, 1998). The mean annual rainfall and ambient temperature range were $1660 \mathrm{~mm}$ and $23.8^{\circ} \mathrm{C}-30.4^{\circ} \mathrm{C}$, respectively.

The second field experiment was established at Pallama Estate, Pallama in the low country dry zone. Agro ecological zone of this area is $\mathrm{DL}_{3}$ (Punyawardena et al., 2003). The experiment site represented the soils belongs to the great soil group of Red Yellow Podzolic (Mapa et al., 2005) with soft or hard laterite (70$90 \%$ ). The mean annual rainfall and ambient temperature range were $1200 \mathrm{~mm}$ and $28^{\circ} \mathrm{C}-$ $32^{\circ} \mathrm{C}$, respectively.

Third field experiment was conducted at Walpita Estate, in low country wet zone. The soil at the site is Red Yellow Podzolic (RYP) (USDA soil taxonomy - Typic Rhodudults) (FAO/UNESCO soil taxonomy - Ferric Altisols) soils with soft and hard laterites (Mapa et al., 2005). The area is characterized by bimodal pattern of rainfall with an annual mean precipitation of $>1700 \mathrm{~mm}$, high ambient air and soil temperature $\left(24 \mathrm{C}^{0}-29 \mathrm{C}^{0}\right)$ and bright sunshine hours (about 6-8 hours day ${ }^{-1}$ ). Reaction of the soil is slightly acidic ( $\mathrm{pH} 4.0-4.5)$ throughout the soil profile. (Mapa et al, 2005). Inall locations, $A$. occidentale trees were cultivated in between coconut rows. Soils of coconut based A. occidentale agroforestry systems were evaluated through a soil fertility analysis by measuring soil physical, chemical and biological properties. Experiment was designed in a Randomized Complete Block Design (RCBD) with three replicates.

$\mathrm{T}_{1}$. Coconut and Cashew (A. occidentale) mix cropping system

$\mathrm{T}_{2}$. Sole coconut system (coconut was established with $8 \mathrm{~m} \times 8 \mathrm{~m}$ spacing)

\section{Soil Sampling, preparation \& analysis}

In December 2013, three soil samples were randomly collected from $2.5 \mathrm{~m}$ away from the effective coconut palms in each experimental plot at $0-15 \mathrm{~cm}, 15-30 \mathrm{~cm}$ and $30-45 \mathrm{~cm}$ depths, respectively. Simultaneously, an undisturbed soil samples were collected using a core-sampler from desired depths $(0 \mathrm{~cm}, 15 \mathrm{~cm}$ and $30 \mathrm{~cm})$ for bulk density determination. Samples were air dried separately at room temperature for $48-72$ hours without any contaminations. Air dried soil samples were crushed and sieved through $2 \mathrm{~mm}$ sieve. Undisturbed soil samples were collected from same locations to determine microbial activity. For physic-chemical characterization the following soil parameters were considered: organic carbon of the samples were measured by Walkey-Black method (Walkley and Black, 1934); N was estimated by the Kjeldahl method (Jackson, 1973) and the $\mathrm{P}$ and $\mathrm{K}$ contents of the samples were analyzed by calorimetric method (Anderson and Ingram, 1993) and flame photometric method (Simard, 1993), respectively. As a soil biological property, microbial activity was determined by trapping $\mathrm{CO}_{2}$ with alkali solutions, followed by the precipitation of carbonates with barium chloride and the titration of any remaining hydroxide with standardised acid (Stotzky, 1965). 


\section{Soil moisture content}

Soil samples were collected from four random points from the $2.5 \mathrm{~m}$ away from the effective coconut palms a depth $0.3 \mathrm{~m}$, to determine potential treatment effects on soil moisture content during dry period (January or July). Collected samples were oven dried at $105^{\circ} \mathrm{C}$ to a constant weight and gravimetric soil moisture content was determined following IAEA (2008).

\section{Data analysis}

Experimental data were analysed following Analysis of Variance (ANOVA) procedure using the statistical software SAS (SAS reference) and the significance of the differences between means was tested using Least Significant Differences (LSD) at $\mathrm{P}=0.05$ (SAS Institute 1999).

\section{Results and Discussion}

Effect of cashew intercropping with coconut on soil physical properties (soil moisture and bulk density)

The soil moisture content was determined during the dry periods in all three locations in Feburary and March months in 2013. The soil moisture content of these three locations are shown in Table 1 . The results showed considerable variation in soil moisture at different depths among three different locations. Sole coconut system had comparatively higher soil moisture content than coconut cashew intercropping system in all three locations. This was attributed to fact that cashew has a well developed deep tap root system which helps to absorb more water through deeper soil layers than coconut. According to the experiment results, the cashew coconut intercropping system had significant effect on soil moisture content at $15-30 \mathrm{~cm}$ and $30-45 \mathrm{~cm}$ soil depths but not at 0 $15 \mathrm{~cm}$ depth at Ratmalagara (intermediate zone) and Walpita (wet zone) locations. However, no significant effect on soil moistuer content at all soil depths that were observed at Pallama (dry zone) location and it is mainly due to the loamy sandy textured nature of the soil.
The cashew intercropping system had a significant effect on soil bulk density at $0-15 \mathrm{~cm}$ and $15 \mathrm{~cm}-30 \mathrm{~cm}$ soil depths, but not at $30-45 \mathrm{~cm}$ soil depths at Ratmalagara and Walpita locations. However, no significant effect on soil bulk density at all selected soil depths at Pallama location where deep loamy sand textured soil can be found.

Comparatively lower soil bulk density was observed in cashew coconut intercropping system than sole coconut system (Table 2). This is mainly due to the fact that intercropping system contributes more organic matter content to the soil than sole coconut system. A high level of organic matter in the soil results in reduced bulk density, improved soil structure, aeration and highwater holding capacity all of which are attributes of a productive soil (Hseih and Hseih, 1990). Soil organic matter is responsible to a great extent, directly or indirectly for making the good physical environment in the soil and making it suitable for the growth of plant roots (Jeyamala and Soman, 1999). Application of organic matter has reduced the bulk density of the soil (Table 2 ), which is a vital soil characteristic for successful root development (Kuchenbuch and Ingram, 2004).

Effect of cashew intercropping with coconut on soil biological properties (soil microbial activity)

The cashew intercropping system had a significant effect on soil microbial activity at 0 $15 \mathrm{~cm}$ soil depth at Ratmalagara and at $0-15 \mathrm{~cm}$ and $15 \mathrm{~cm}-30 \mathrm{~cm}$ soil depths at Walpita (Table 3 ). However, no significant effect on soil microbial activity at all soil depths at Pallama. Higher soil microbial activity was observed in cashew coconut intercropping system compared to the sole coconut system and this is mainly due to the reason that intercropping practice contributes more organic matter to the system.

The application of organic matter to the soil is considered as a good management practice as it stimulates soil microbial growth and activity with subsequent mineralization of plant nutrients (Eriksen, 2005); and thereby, increase soil fertility and quality (Doran et al., 1988). 
Table 1. Effect of growing cashew (A. occidentale) on soil physical properties (soil moisture)

\begin{tabular}{|c|c|c|c|c|c|c|c|c|c|}
\hline \multirow{3}{*}{ Treatments } & \multicolumn{9}{|c|}{ Soil moisture (\%) } \\
\hline & \multicolumn{3}{|c|}{$\begin{array}{c}\text { Ratmalagara (intermediate } \\
\text { zone) }\end{array}$} & \multicolumn{3}{|c|}{ Pallama (dry zone) } & \multicolumn{3}{|c|}{ Walpita (wet zone) } \\
\hline & $0-15 \mathrm{~cm}$ & $\begin{array}{c}15- \\
30 \mathrm{~cm}\end{array}$ & $\begin{array}{c}30- \\
45 \mathrm{~cm}\end{array}$ & $0-15 \mathrm{~cm}$ & $\begin{array}{c}15- \\
30 \mathrm{~cm}\end{array}$ & $\begin{array}{c}30- \\
45 \mathrm{~cm}\end{array}$ & $0-15 \mathrm{~cm}$ & $\begin{array}{c}15- \\
30 \mathrm{~cm}\end{array}$ & $\begin{array}{c}30- \\
45 \mathrm{~cm}\end{array}$ \\
\hline $\mathrm{T}_{1}$ & 10.88 & 8.46 & 6.23 & 9.23 & 8.11 & 7.18 & 12.54 & 13.44 & 8.95 \\
\hline $\mathrm{T}_{2}$ & 11.41 & 12.58 & 10.46 & 9.45 & 12.34 & 10.23 & 18.96 & 21.52 & 20.69 \\
\hline Significance & NS & $*$ & $*$ & NS & NS & NS & $*$ & * & $*$ \\
\hline LSD $(\mathrm{P}<0.05)$ & - & 3.34 & 3.81 & - & - & - & 5.42 & 6.78 & 9.12 \\
\hline
\end{tabular}

* Significantly different at $\mathrm{P}=0.05$; NS- not significant

Table 2. Effect of growing cashew (A. occidentale) on soil physical properties (soil bulk density)

\begin{tabular}{|c|c|c|c|c|c|c|c|c|c|}
\hline \multirow{3}{*}{ Treatments } & \multicolumn{9}{|c|}{ Bulk density $\left(\mathrm{g} \mathrm{cm}^{-3}\right)$} \\
\hline & \multicolumn{3}{|c|}{ Ratmalagara } & \multicolumn{3}{|c|}{ Pallama } & \multicolumn{3}{|c|}{ Walpita } \\
\hline & $\begin{array}{c}0- \\
15 \mathrm{~cm}\end{array}$ & $\begin{array}{c}15- \\
30 \mathrm{~cm}\end{array}$ & $\begin{array}{c}30- \\
45 \mathrm{~cm}\end{array}$ & $0-15 \mathrm{~cm}$ & $\begin{array}{c}15- \\
30 \mathrm{~cm}\end{array}$ & $\begin{array}{c}30- \\
45 \mathrm{~cm}\end{array}$ & $0-15 \mathrm{~cm}$ & $\begin{array}{c}15- \\
30 \mathrm{~cm}\end{array}$ & $\begin{array}{c}30- \\
45 \mathrm{~cm}\end{array}$ \\
\hline $\mathrm{T}_{1}$ & 1.43 & 1.51 & 1.58 & 1.64 & 1.58 & 1.54 & 1.26 & 1.31 & 1.36 \\
\hline $\mathrm{T}_{2}$ & 1.71 & 1.78 & 1.64 & 1.76 & 1.65 & 1.72 & 1.45 & 1.42 & 1.41 \\
\hline Significance & $*$ & * & NS & NS & NS & NS & * & $*$ & NS \\
\hline LSD $(\mathrm{P}<0.05)$ & 0.18 & 0.22 & - & - & - & - & 0.12 & 0.08 & - \\
\hline
\end{tabular}

* Significantly different at $\mathrm{P}=0.05$; NS- not significant

Table 3. Effect of growing cashew (A. occidentale) on soil biological properties (soil microbial activity)

\begin{tabular}{|c|c|c|c|c|c|c|c|c|c|}
\hline \multirow{3}{*}{ Treatments } & \multicolumn{9}{|c|}{ Microbial activity (mg/day) } \\
\hline & \multicolumn{3}{|c|}{ Ratmalagara } & \multicolumn{3}{|c|}{ Pallama } & \multicolumn{3}{|c|}{ Walpita } \\
\hline & $0-15 \mathrm{~cm}$ & $\begin{array}{c}15- \\
30 \mathrm{~cm}\end{array}$ & $\begin{array}{c}30- \\
45 \mathrm{~cm}\end{array}$ & $0-15 \mathrm{~cm}$ & $\begin{array}{c}15- \\
30 \mathrm{~cm}\end{array}$ & $30-45 \mathrm{~cm}$ & $0-15 \mathrm{~cm}$ & $\begin{array}{c}15- \\
30 \mathrm{~cm}\end{array}$ & $\begin{array}{c}30- \\
45 \mathrm{~cm}\end{array}$ \\
\hline $\mathrm{T}_{1}$ & 69.4 & 55.7 & 56.8 & 34.4 & 26.7 & 18.4 & 88.2 & 94.5 & 66.7 \\
\hline $\mathrm{T}_{2}$ & 51.6 & 48.1 & 48.2 & 29.4 & 22.9 & 25.1 & 72.4 & 63.1 & 58.3 \\
\hline Significance & * & NS & NS & NS & NS & NS & $*$ & $*$ & NS \\
\hline LSD $(\mathrm{P}<0.05)$ & 10.2 & - & - & - & - & - & 8.6 & 23.1 & - \\
\hline
\end{tabular}

* Significantly different at $\mathrm{P}=0.05$; NS- not significant 
Effect of cashew intercropping with coconut on soil chemical properties (soil organic matter content, available $P$, total $N$ and exchangeable $\mathrm{K}$ )

\section{Soil organic matter content (\%)}

The cashew intercropping system had a significant effect on soil organic matter content in all the locations. The highest valueswere observed at $0-15 \mathrm{~cm}$ depth at Ratmalagara and Walpita locations (Table 4). Soil organic matter content of deeper soil layers showed different dynamic compared top soil layers in three locations. Intestinally, soil organic matter content did not show any significant differences in sub soil from $15-30 \mathrm{~cm}$ depth and $30-45 \mathrm{~cm}$ depth in Pallama location.

This result reconfirms that organic inputs from cashew intercropping system have a constructive effect on soil organic matter content in soils of three locations. Moreover, Utomo et al., (1990) and Reddy et al., (2003) reported that SOM amelioration following leaf manure incorporation up to $1 \%$ of total soil mass. Nonetheless, substantial soil organic matter content were recorded from Rathmalagara and Walpita compared to the Pallama. This may associate to inherent low soil organic matter content in dry zone soils and rapid oxidation process in dry regions (Srinivasarao et al., 2008). Cashew coconut intercropping system has showed more accumulation of organic matter in surface soil compared to subsoil in both locations lining with the study by Rudrappa (2006), who reported that soil organic matter was found stratified along the soil depth.

\section{Soil total nitrogen, available $P$ and exchangeble $\mathrm{K}$}

Mean values of soil nutrients at different soil depths under coconut cashew mixcropping systems in three different locations are presented in Tables 5, 6 and 7. The cashew intercropping system had no significant effect on soil total $\mathrm{N}$ at Ratmalagara and Pallama locations. However, significant effect has been shown on soil total nitrogen at top soil layers $(0-15 \mathrm{~cm}$ and $15-30 \mathrm{~cm})$ at Walpita locaton. In this location, higher total $\mathrm{N}$ content was observed in sole coconut planting system compared to the cashew coconut intercropping system. The higher value in sole coconut system can be explained in terms of symbiotic relationship of the dense herbaceous undergrowth that releases or fixed nitrogen and rapid humification. The relatively lower mean values in mixed cropping may be attributed by inadequate application of nitrogen based chemical fertilizers, increasing immobilization by plants and leaching and volatization which is common to most mineral soils (Jones and Weld, 1975; Brady and Weil, 2002).

Cashew growing with coconut had no significant impact on available phophorus content in soil at three different loactions (Table 6). However, available $\mathrm{P}$ content in soil was higher in sole coconut system and the value has been decreased with the soil depth. The higher content of available P in surface soil compared to sub soil can be ascribed to the accumulation of leaf litter besides supplementing the depleted nutrients through external sources. The lower phosphorus content in sub soil horizones might be attributed by the fixation of released P by clay minerals and oxides of iron and Aluminium (Leelavathi et al., 2009).

The values of excahngable $\mathrm{K}$ as reveled in Table 7, shows that the sole coconut system has comparatively higher $\mathrm{K}$ content compared to the coconut cashew mix cropping system. The exchangeable $\mathrm{K}$ content is generally lower for mixed cropping while the mono-cropping has a slight higher value. The variation in the base elements across the three sites will be reflected in the growth rate as well as the translocation and storage of carbohydrates and proteins into different palnt parts. The comparatively lower values of this mix cropping system may be a reflection of losses through leaching, cultivation or harvesting (Jaiyeoba, 1995).

\section{Implications of the Study}

As a result of general reduction in the contents of the different soil properties under the two cropping systems (sole coconut and coconut cashew system), a significant variation in crop production is expected. The analysis of variance revealed that the mean of the some soil parameters were significantly different from 
Table 4. Effect of growing cashew (A. occidentale) on soil organic matter content (\%)

\begin{tabular}{|c|c|c|c|c|c|c|c|c|c|}
\hline \multirow{3}{*}{ Treatments } & \multicolumn{9}{|c|}{ Organic matter content $(\%)$} \\
\hline & \multicolumn{3}{|c|}{ Ratmalagara } & \multicolumn{3}{|c|}{ Pallama } & \multicolumn{3}{|c|}{ Walpita } \\
\hline & $0-15 \mathrm{~cm}$ & $\begin{array}{c}15- \\
30 \mathrm{~cm}\end{array}$ & $\begin{array}{c}30- \\
45 \mathrm{~cm}\end{array}$ & $0-15 \mathrm{~cm}$ & $\begin{array}{c}15- \\
30 \mathrm{~cm}\end{array}$ & $\begin{array}{c}30- \\
45 \mathrm{~cm}\end{array}$ & $0-15 \mathrm{~cm}$ & $\begin{array}{c}15- \\
30 \mathrm{~cm}\end{array}$ & $\begin{array}{c}30- \\
45 \mathrm{~cm}\end{array}$ \\
\hline $\mathrm{T}_{1}$ & 2.45 & 1.59 & 0.95 & 0.84 & 0.78 & 0.47 & 2.66 & 2.35 & 1.04 \\
\hline $\mathrm{T}_{2}$ & 1.38 & 1.12 & 0.81 & 0.99 & 0.75 & 0.58 & 1.42 & 1.59 & 0.92 \\
\hline Significance & $*$ & * & NS & * & NS & NS & $*$ & $*$ & NS \\
\hline LSD $(\mathrm{P}<0.05)$ & 1.02 & 0.27 & - & 0.14 & - & - & 0.98 & 0.37 & - \\
\hline
\end{tabular}

* Significantly different at $\mathrm{P}=0.05 ; \mathrm{NS}$ - not significant

Table 5. Effect of growing cashew on soil total $\mathbf{N}(\mathrm{ppm})$ content

\begin{tabular}{|c|c|c|c|c|c|c|c|c|c|}
\hline \multirow{3}{*}{ Treatments } & \multicolumn{9}{|c|}{ Total nitrogen (ppm) } \\
\hline & \multicolumn{3}{|c|}{ Ratmalagara } & \multicolumn{3}{|c|}{ Pallama } & \multicolumn{3}{|c|}{ Walpita } \\
\hline & $0-15 \mathrm{~cm}$ & $\begin{array}{c}15- \\
30 \mathrm{~cm}\end{array}$ & $\begin{array}{c}30- \\
45 \mathrm{~cm}\end{array}$ & $0-15 \mathrm{~cm}$ & $\begin{array}{c}15- \\
30 \mathrm{~cm}\end{array}$ & $\begin{array}{c}30- \\
45 \mathrm{~cm}\end{array}$ & $0-15 \mathrm{~cm}$ & $\begin{array}{c}15- \\
30 \mathrm{~cm}\end{array}$ & $\begin{array}{c}30- \\
45 \mathrm{~cm}\end{array}$ \\
\hline $\mathrm{T}_{1}$ & 569.6 & 521.2 & 458.4 & 326.5 & 359.4 & 264.7 & 602.4 & 652.1 & 482.6 \\
\hline $\mathrm{T}_{2}$ & 572.4 & 541.3 & 486.1 & 374.6 & 402.5 & 285.1 & 634.8 & 721.2 & 504.4 \\
\hline Significance & NS & NS & NS & NS & NS & NS & $*$ & $*$ & NS \\
\hline $\begin{array}{c}\text { LSD } \\
(\mathrm{P}<0.05)\end{array}$ & - & - & - & - & - & - & 29.5 & 17.26 & - \\
\hline
\end{tabular}

* Significantly different at $\mathrm{P}=0.05$; NS- not significant

Table 6. Effect of growing cashew on soil available $P$ (ppm) content

\begin{tabular}{|c|c|c|c|c|c|c|c|c|c|}
\hline \multirow{3}{*}{ Treatments } & \multicolumn{9}{|c|}{ Available P (ppm) } \\
\hline & \multicolumn{3}{|c|}{ Ratmalagara } & \multicolumn{3}{|c|}{ Pallama } & \multicolumn{3}{|c|}{ Walpita } \\
\hline & $\begin{array}{c}0- \\
15 \mathrm{~cm}\end{array}$ & $\begin{array}{c}15- \\
30 \mathrm{~cm}\end{array}$ & $\begin{array}{c}30- \\
45 \mathrm{~cm}\end{array}$ & $0-15 \mathrm{~cm}$ & $\begin{array}{c}15- \\
30 \mathrm{~cm}\end{array}$ & $\begin{array}{c}30- \\
45 \mathrm{~cm}\end{array}$ & $0-15 \mathrm{~cm}$ & $\begin{array}{c}15- \\
30 \mathrm{~cm}\end{array}$ & $\begin{array}{c}30- \\
45 \mathrm{~cm}\end{array}$ \\
\hline $\mathrm{T}_{1}$ & 1.55 & 1.49 & 0.71 & 1.54 & 1.11 & 0.92 & 3.54 & 1.28 & 0.91 \\
\hline $\mathrm{T}_{2}$ & 1.73 & 1.52 & 0.84 & 1.62 & 0.98 & 0.86 & 4.18 & 1.41 & 1.11 \\
\hline Significance & NS & NS & NS & NS & NS & NS & NS & NS & NS \\
\hline $\begin{array}{c}\text { LSD } \\
(\mathrm{P}<0.05)\end{array}$ & - & - & - & - & - & - & - & - & - \\
\hline
\end{tabular}

* Significantly different at $\mathrm{P}=0.05 ; \mathrm{NS}$ - not significant 
Table 7. Effect of growing cashew on soil exchangeable K (meq/100g)

\begin{tabular}{|c|c|c|c|c|c|c|c|c|c|}
\hline \multirow{3}{*}{ Treatments } & \multicolumn{9}{|c|}{ Exchangeable $K$ content (meq $100 \mathrm{~g}^{-1}$ soil ) } \\
\hline & \multicolumn{3}{|c|}{ Ratmalagara } & \multicolumn{3}{|c|}{ Pallama } & \multicolumn{3}{|c|}{ Walpita } \\
\hline & $\begin{array}{c}0- \\
15 \mathrm{~cm}\end{array}$ & $\begin{array}{c}15- \\
30 \mathrm{~cm}\end{array}$ & $\begin{array}{c}30- \\
45 \mathrm{~cm}\end{array}$ & $\begin{array}{c}0- \\
15 \mathrm{~cm}\end{array}$ & $\begin{array}{c}15- \\
30 \mathrm{~cm}\end{array}$ & $\begin{array}{c}30- \\
45 \mathrm{~cm}\end{array}$ & $\begin{array}{c}0- \\
15 \mathrm{~cm}\end{array}$ & $\begin{array}{c}15- \\
30 \mathrm{~cm}\end{array}$ & $\begin{array}{c}30- \\
45 \mathrm{~cm}\end{array}$ \\
\hline $\mathrm{T}_{1}$ & 0.172 & 0.178 & 0.116 & 0.201 & 0.163 & 0.141 & 0.382 & 0.522 & 0.371 \\
\hline $\mathrm{T}_{2}$ & 0.181 & 0.191 & 0.137 & 0.269 & 0.181 & 0.157 & 0.431 & 0.596 & 0.402 \\
\hline Significance & NS & NS & NS & * & NS & NS & NS & NS & NS \\
\hline $\operatorname{LSD}(\mathrm{P}<0.05)$ & - & - & - & 0.022 & - & - & - & - & - \\
\hline
\end{tabular}

* Significantly different at $\mathrm{P}=0.05$; NS- not significant

each other in the three locations. This implies that the cropping systems constitute a threat to soil fertility and agricultural productivity. It also implies that different cropping systems effect changes in the content of the soil elements and the rate of nutrient immobilization. This will therefore require different management strategies to sustain soil fertility in this area.

\section{Conclusion}

Generally, the study revealed that the contents of the soil chemical, physical and biological properties are vary with the cropping system and the location. However, cashew trees do not compete significantly with coconut palms for major soil nutrients (N, P and $\mathrm{K}$ ) and this mix cropping system enhance the organic matter content of the soil. This system has significantly reduced the soil moisture content of the soil except in dry zone and as a result cashew and coconut yield can be affected negatively. Therefore, proper agronomic practices should be followed to conserve soil moisture as well as the soil fertility in coconut cashew intercrop mix cropping system.

\section{References}

Alavalapati, J.R.R., Shrestha, R.K., Stainback, G.A., Matta, J.R. 2004. Agroforestry development: an environmental economic perspective. Agrofor Syst 61:299-310.

Anderson, J.M. and Ingram, J.S.I. 1993. Tropical Soil Biology and Fertility. A Handbook of
Methods 2nd ed. Wallingford, UK: CABI Publishing. pp221.

Arnold, J. E. M. 1997. Retrospect and prospect. In farms, trees and farmers: Responses to agricultural intensification. J. E. M. Arnold and Peter A. Dewees (eds.). pp 271-287. Earthscan, London.

Bonneau, X. and Sugarianto, J. 1999. Intercropping with young hybrid coconut palms in climatically marginal areas. Plant. Rech. Dévelop. 6(1):13-29.

Brady, N. C., and Weil, R. R. 2002. The Nature and Properties of Soils ( $13^{\text {th }}$ edition). New Jersey: Prentice Hall.

Burgess, R.J. 1981. The Intercropping of Smallholder Coconuts in Western Samoa; An Analysis Using Multi-Stage Linear Programming. Development Studies Centre, MADE Research Series No. 4. The Australian National University, Canberra.

De Costa, W.A.J.M., Sangakkara, U.R. 2006. Agronomic regeneration of soil fertility in tropical Asian smallholder uplands for sustainable food production. J. Agric. Sci., 144, 111-133.

Doran, J.W., Fraser, D.G., Culik, M.N., Liebhardt, W.C. 1988. Influence of alternative and conventional agricultural management on soil microbial process and 
nitrogen availability. Am. J. Alternative Agric. 2, 99-106.

Eriksen, J. 2005. Gross sulphur mineralizationimmobilization turnover in soil amended with plant residues. Soil Biol. Biochem. 37, 2216-2224.

Fernando, L.H., Asghar, M and Opio, F. 1984. A review of small-scale production and marketing of coconut in Western Samoa. Alafua Agricultural Bull. 9(1), 1-29.

Hsieh, H.C. and Hsieh, C.F. 1990. The use of organic matter in Crop Production, Food and Fertilizer Technology Centre Taipei, China, Extension Bulleting No. 315: 18.

Jackson, M.L. 1973. Soil Chemical Analysis (1 $1^{\text {st }}$ Ed), Prentice Hall of India Private Limited, New Delhi, 111-204.

Jaiyeoba, I.A. 1995. Changes in Soil Properties Related to Different Land uses in part of Nigerian Northern Savanna. Soil Use and Management, 11, 84-89.

Jeyamala, M. and Soman P. 1999. Short term changes in soil fertility status in intensively managed Teak plantation. Indian Journal of Forestry, 22: 106-111.

Jones, M.J., and Weld, A. 1975. Soils of the West African Savanna: The Maintenance and Improvement of their Fertility. Haependen Commonwealth Agricultural Bureau. Kwara State of Nigeria. Kwara State Diary, Government Press Ilorin (1993).

Jose, S. 2009. Agroforestry for ecosystem services and environmental benefits: an overview. Agrofor Syst 76:1-10.

Kuchenbuch, R.O. and Ingram, K.T. 2004. Effects of soil bulk density on seminal and lateral roots of young maize plants (Zea mays L.). Journal of Plant Nutrition and Soil Science, 167, 229-235.

Leelavathi, G.P., Naidu, M.V.S and Ramaratharam, N. 2009. Studies on genesis, classification and evaluation of soils for sustainable land use planning in Yerpedu Mandal of Chittor district,
Andhra Pradesh. Journal of the Indian Socity of Soil Science, 57; 109-120.

Liyanage, M. de S. and Dassanayake, K.B. 1993. Experiences in coconut based farming systems in Sri Lanka. In: Advances in Coconut Research and Development (eds. Nair, M.K., et al.). Proc. of Intern. Sympos., Kasaragod 26-29 Nov. 1991, 357-367. Indian Soc. for Plantation Crops.

Liyanage, M., Tejwani, S.K.G. and Nair, P.K.R. 1985. Intercropping under coconut in Sri Lanka. Agroforestry Systems 2:215-228.

Long, A.J. and Nair, P.K.R. 1999. Trees Outside Forests: Agroforestry, Community, and Urban Forestry. New Forests 17(1-3): 145-174.

Magat, S.S. 2004. Growing of intercrops in coconut lads to generate more food and agricultural products, jobs and enhancing farm incomes. Coconut intercropping Salient notes. Dept. of Agric., Phillippine Coconut Authority, Quezon City, Philip pines, pp. 7.

Mapa, R.B., Dassanayake, A.R. and Nayakekorale, H.B. 2005. Soils of the Intermediate zone of Sri Lanka: morphology, characterization and classification. Soil Science Society of Sri Lanka, Peradeniya, Sri Lanka.

Nair, P.K.R. 1985. Classification of agroforestry systems. Agroforesty Systems, 3; 97-128.

Nelliat, E.V., K.V. Bavapp and P.K.R. Nair 1974. Multistoreyed cropping. A new dimension cropping for coconut plantations. World Crops. 26 (6): 262-266.

Ohler, J.G. 2007. Modern coconut management; palm cultivation and products. FAO, Rome. http://ecoport.org/ep? Search Type $=$ earticleView\&earticleld $=127 \& p a$ $\mathrm{ge}=1383$.

Opio, F.A. 1990. The need for coconut based systems. In: Coconut Based Farming Systems (ed. Silva de, S.), Proc. of the XXVII COCOTECH Meeting, 25-29 June, Manila, Philippines, 1-15. 
Punyawardena, B.V.R., Bandara, T.M.J., Munasinghe, M.A.K. and Banda, N.J. 2003. Agroecological regions of Sri Lanka. Natural Resources Management Centre, Department of Agriculture, Peradeniya, Sri Lanka.

Reddy, K., Zablotowicz, R.M., Locke, M.A. and Koger 2003. Cover crop, tillage and herbicide effects on weeds, soil properties, microbial population, and soybean yields. Weed Science, 51, pp. 987-994.

Regmi, B.N. and Garforth, C. 2010. Trees outside forests and rural livelihoods: a study of Chitwan district, Nepal. Agroforesty Systems, 79; (3); 393-407.

Rudrappa, L., Purakayastha, T.J., Singh, D. and Bhadraray, S. 2006. Long-term manuring and fertilization effects on soil organic carbon pools in a Typic Haplustept of semi-arid sub-tropical India. Soil and Tillage Research, 88, pp. 180-192.

[SAS] Statistical Analysis Systems, 1999. SAS 1, STAT Users Guide, Release, 7.00 Cary, NC: Statistical Analysis Systems Institute, 1028.

Simard, R.R. 1993. Ammonium acetate Extractable Elements. In: Martin R, Carter $\mathrm{S}$ (Eds) Soil sampling and methods of analysis, Lewis Publisher, Florida, USA, $39-43$
Srinivasarao, Ch., Vittal, K.P.R., Gajbhiye, P.N., Sumanta Kundu and Sharma, K.L. 2008. Distribution of micronutrients in soils in rainfed production systems of India. Indian Journal of Dryland Agricultural Research and Development, 21, pp. 105113.

Stotzky, L.M. Chemical and microbiological properties. In: black, C.A.E.; white, J.L.; Ensminger, L.E. \& Clarke, F.E., ed. Methods of soil analysis. Madison, Soil Science Society of America, 1965. v.2. p.1550-1572.

Tamale, E., Jones, N. Riddihough, I. P. 1995. Participatory forestry in tropical and sub tropical countries. World Bank forestry series. Technical paper number 299.

Utomo, M., Frye, W.W. and Blevins, R.L. 1990. Sustaining soil nitrogen for soil using hairy vetch cover crop. Agronomy Journal, 82, pp. 979-983.

Walkley, A. and I.A. Black, 1934. An Examination of the Degtjareff Method for Determining Soil Organic Matter and Prepared Modification of the Chronic Acid Titration Method. Soil Science, 34, 29-38.

Weerakoon, S. 2011. A new lease of life for cashew industry. Available online at http://www.sundayobserver.1k/2011/07/31 /fea1. 